\title{
Impact of Landscaping of Shopping-Mall on Customer Preferences: A Qualitative Study of Shopping Malls located in Karachi
}

\author{
Shahzad Nasim, \\ Hamdard University \\ Musarrat Shamshir \\ Hamdard University
}

\begin{abstract}
This study aims at finding the impact of landscaping variables such as interior design, décor and other atmospheric variables of shopping malls on the customers' preferences and purchase intentions. The research is descriptive in nature and is conducted on the shopping malls of the Karachi; a metropolitan city of Pakistan. Data is gathered through interviews of the customers who visited shopping malls frequently. Semi structured questionnaire and content analysis of interviews is used for the analysis of the results. The findings of this study specify that variables like hygiene, aroma, lighting, and display/layout have significant impact on customers' purchase intention; whereas temperature, music and color found to be insignificant variables.
\end{abstract}

Keywords: Landscaping of shopping mall, Customer preference, Qualitative study. 


\section{INTRODUCTION}

Shopping malls in Karachi is growing day by day in size and quantity, their one-stop suitability has prolonged to embrace numerous retail stores, service outlets, and entertainment providers (Akram, et al., 2016). Malls are not increasing intensely, but they are also aligning with quality and features of the malls. Shopping centers ought to be planned as genuinely open spaces with abundant open areas incorporate attributes, for example food court, atrium, a ramp for fashion show, large area for musical concerts and children play area with a dynamic water flow, renowned spots, gardens, civic and social activities (Hami, et al., 2018). Shopping centers can be seen as open spaces, requiring scientific and suitable insight to finishing of their open spaces

(Chithralega , 2013). The right landscaping makes the retail site more attractive, welcoming and comfortable. The interior design and décor of shopping malls may increase the footfall in the shopping malls, ultimately could result in increased shopping intentions.

It has been observed that the numbers of shopping malls in Karachi has been increase in last five years. According to Bhuvaneswari, et al. (2015), Shopping mall is one of that places which communicate with consumer behavior, their experience and their feelings. Information of people preferences related to various attribute within the malls should be considered prudently at utmost priority. This information may have an impact on making an indoor useful space giving reasonable conveniences and an agreeable domain for the visitors.

Various researchers have conducted researches on measurement of shoppers' behavior in shopping mall (Kaihatu \& Spence, 2016). In spite of the amalgamated body of knowledge related to the impact of shopping mall interior landscape design on shoppers this paper addresses the importance of interior design of the shopping mall for their customers. This study may contribute in providing profitable and unique information from customers for the optimal designing of shopping malls in future. This article means to recognize the factors for individuals' inclinations towards shopping centers in Karachi.

\section{LITERATURE REVIEW}

Shopping mall is a great place where most of people come from different region for shopping (Koul \& Mishra, 2013). Various attributes in a shopping mall like beautiful and comfortable environment comprising of food and play area, movie theater fascinate and attract people to go for shopping (Dębek, 2015). Features such as flat screen videos, graphics, aromas, lighting and flooring tend to capture the brand image or personality and help to create a unique atmosphere and shopping experience for the people (Mittal \& Jhamb, 2016). Music is another way of entertainment to keep them enchanted during their stay at shopping mall. Customers attract towards the mall due to good, clean atmosphere, lighting and clear display of products (Hussain \& Ali, 2015). 
(Ekeng et al.2012) explore in his study that the shopping malls should designed according to the customer's demographic characteristics and the main demographic factor is the income of the shoppers because this factor decide the product type and quality through which the designers arrange the malls according to demographic characteristics of the shoppers.

According to (Šeinauskienė, et al. 2015) customers visit shopping malls not only for searching particular products, buying groceries, homeware and the use of mall facilities such as cash withdrawals and paying accounts at automated teller machines but they also visit malls as an entertainment activity that provides fun and pleasure such as watching movies, celebrate special occasions, and for eating out especially. The public shopping malls should be designed according to public preferences. Public prefer most the green dimension in which the garden, water flows, seating area should be there (Hami et al., 2018). Furthermore, public prefers mall shopping due to location of the mall, accessibility, relaxed shopping environment, product knowledge, price equality or discounted price and entertainment (Thomas \& Pathak, 2012). The consumers visit shopping malls frequently not for shopping only, but the atmosphere and other facilities compels them to come and window display persuade them to purchase different products from there (Makgopa, 2016). The purchasers perhaps attracted from side to side because of the variety of products, merchandising, convenience and consumer satisfaction prevailing in shopping malls in context of global consumer intension (Mittal \& Jhamb, 2016).Individuals usually wish to go their nearby convenience store for buying thing and the exterior store atmosphere also fascinate the shopper to enter in the mall furthermore internal attractive environment reflects individuals to go shopping on that place if it is mall or store (Ali \& Mubarak, 2011).

The Consumer purchase intention may be prompted by cleanliness, scent, lighting, music, temperature and display of the product in showcase. Some atmospheric variables such as cleanliness, scent, lighting, and display have a positive influence on consumers' purchase intention (Hussain \& Ali , 2015). The exterior atmospheres or look of the shopping mall or retail shop is also the great source of consumer attraction. Some features like the footsteps of the shops and malls, window display, land escaping (Ali \& Mubarak, 2013). The mall is an important gathering place where adolescents often socialize and develop connections and community living skills. According to (Dahan-Oliel et al., 2016) adolescents aged between 12 and 19 with disabilities may participate in purchasing-decisions if appropriate facilities and respected environment with high quality public access are provided in the shopping malls. Shoppers may be attracted towards the shopping mall because they go shopping centre not only for shopping but even some enjoyments or window shopping. According to Kumar \& Singh (2014) availability of brand, quality and variety of product, alternative and ease to find the product are main affecting factors for appealing customer towards mall. Another factor is safety and security which affect customers to shopping in mall with family and children. Albrecht et al. (2017) describes that store appearance can affect the human behavior and attractive feature of the mall including pleasant environment prevent the shoppers from stress and made them easy and relax. 
The shopping malls have mystic to pull the customers towards it and this is the strategy that the designers and constructor of the malls adopted (Goss, 1993). Furthermore, by providing spacious outlets to the products the malls work like the magician for the consumers' attraction and create profit at the same time. According to one survey of shopping mall it has been observed that features of the malls like food court, security with transport facility, position of shopping, the promotions, celebrity events, book launch, movie promotions, music concerts establish a relation between the shoppers and the mall. The malls are not place for shopping but are place of get together; spend quality leisure time (Shaikh, 2017). Rabbanee et al. (2012) found positive relationships among perceived value of store, store loyalty, store relationship commitment, distance and shopping mall.

Choudhury et al. (2012) found in his study on Bangladesh that customers attract towards the mall due to their convenience, quality and availability of product, price, facility to socialize, food facility, entertainment and overall services.

Generally, atmosphere and facilities of the shopping malls including discount price, low price, parking area, play land for children, hall for the discussion, counter on each floor attract the consumer towards shopping malls they want to visit the shopping malls not only for the shopping but also for enjoyment (Makgopa, 2016). Shoppers prefer shopping centers for different reasons like accessibility of branded product, quality and assortment of product, accessibility of branded product, alternative and comfort of find product (Kumar \& Singh, 2014). Additionally, shopping malls is one of that places where sellers interact with consumers and identify the need of their customers from their involvement and try to articulate future strategy or plain to provide a better environment of the mall (Avello et al, 2011). According to (Hasker \& Inci, 2014) existence of parking area at the mall make the customers relaxed and focused for shopping in shopping mall. Free provision of parking is a robust result. It draws a great image of the mall in the customer eyes so it is better that free parking space provide to the customer. According to (Das \& Varshneya, 2017) shoppers, feel pleased while shopping at the mall which is nearby their home and malls are familiar not only for the purpose of the shopping but also for the enjoyment by watching movie.

\section{RESEARCH METHODOLOGY}

The research is descriptive in nature and is conducted on the shopping malls of the Karachi; a metropolitan city of Pakistan. In this study qualitative research design is used to describe the consumer experiences and explore the impact of shopping malls on customer satisfaction. An inductive research approach is used to find the reason of public preferences towards shopping mall due to its interior landscape design. Data is gathered through interviews of the customers who visited shopping malls frequently. Semi structured questionnaire and content analysis of interviews is used for the analysis of the results. Homogenous and criterion sampling techniques is used in this study. To identify the attractive features of the mall social constructive philosophical paradigm is used. For measuring the impact of shopping mall interior landscape design on consumer interpretive research paradigm is castoff. Primary data is collected by conducting semi structured interviews of 25 consumers from 
eight different shopping malls. Semi structured interviews using open ended questions is piloted. During conducting interviews audio of the consumer is recoded after getting permission of the respondent then transcript of that recoded interviews is prepared and coded manually. To generate the results and findings transcripts of Interviews has been prepared. Narrative and content analysis has been done to find out the answers of research questions. Content analysis technique is used to examine the informational contents of textual data (Mayring, 2004). There are numerous kind of content analysis, all types of analysis are sharing the central features of systematically categorizing textual data (Huberman \& Miles, 1994). In this section, we represent a qualitative content analysis in which different categories or themes are derived from the data, applied through close reading and analyzed entirely qualitatively. The generation and application of categories that we describe can also be used in studies that include quantitative analysis. This study addresses three research questions;

1. Why shopping malls are increasing day by day in the cities?

2. Why people prefer to go shopping mall instead of the nearest retail shop?

3. How shopping malls can improve their infrastructure according to demand of the customer?

\section{FINDINGS AND DISCUSSION}

After examining the data with the help of content analysis of interviews which is comprises of transcript, coding, making theme and finally matching with the objectives of the study, it is explored that store appearance, landscaping and window display have significant and positive impact on consumer behavior. The variables like hygiene, aroma, lighting, and display/layout have significant impact on customers' purchase intention; whereas temperature, music and color found to be insignificant variables.

Consumer's always go in mall for shopping where they can receive special attention through different and modern landscapes like physical environment of the mall. They prefer to visit that shopping centers whose image is most consistent with the modern life style that's why importance of store image cannot be ignore in the society. In Pakistan customers are more motivated towards stylish shopping centres and they love and enjoye their shopping under one roof with eating. As mention in Interview Q\#3 respondents clearly describe the difference between traditional bazar and super store or shopping mall. The basic purpose of staying long time in the mall is to get multiple products under one roof. Customer creates the image by word of mouth and personal experience.

Interview Q \# 3: What is the difference between Super store and Bazaar?

Respondent 1: In Super store we can easily find and buy things while in Bazaar we face inconvenience.

Respondent 2: Super stores are far better than bazaar as we get everything in one platform rather than wandering here and there for shopping.

Respondent 3: Super stores are best as compare to bazar because we can individually and easily purchase each and every thing happily and safely. 
Respondent 4: There is a big difference b/w store and bazar, we can buy anything in one compound in super store while in bazar have to searching, bargaining then finding the required product.

Respondent 5: We can get everything from super store like garments, makeup, and grocery etc. in neat and clean environment but in bazaar we have to face many problems like snatching, bargaining, dusting etc.

Respondent 6: In bazar there is a huge crowd but it easy to do shopping in super store because it is centralized with Air Condition and cameras.

Respondent 7: In my opinion the Super markets are more convenient than Bazaar. Because of fixed price, quality of products is more satisfied and all things are easily available.

Respondent 8: In super store everything is available at fixed price, specific display area and in fully hygiene condition.

Varley (2005) proposed that the store and its atmosphere play a major role in the formation and maintenance of business image.According to respondents in response to interview $\mathrm{Q} \# 7$;

Interview Q\# 7: What comes in your mind while selecting super store?

Respondent 1: We can buy things of different varieties according to our choice.

Respondent 2: We can do shopping in a good environment.

Respondent 3: Environment of the mall, computerize billing, gaming zone and quality of product.

Respondent 4: We can buy things in discounted rates in very pleasant atmosphere. Respondent 5: One solution for every shopper; like discounted price, good environment, food item, sales man guideline, variety of product etc.

Respondent 6: We can find different types of brands in one place.

Respondent 7: Reasonable prices, quality guarantee, saving time and all things under one roof.

Respondent 8: Pleasant and appealing environment including A.C, showcase of the products, good presentation of product.

Products in retail chains should be displayed in a way that appeals to consumers. Product display in retail stores is a stimulating factor for attracting consumers to impulse purchases (Abratt \& Goodey, 1990). The design and display of products in retail chains contributes to a quarter of sales points (Hussain \& Ali, 2015).

A display can be defined as a set of products, shelf space and space allocation, departmental allocation and wall decoration. Design is defined as the division of the sales area, the space used and the layout of the product (Banat \& Wandebori, 2012). The product display has a great influence on the consumer's willingness to purchase and the customer's perception of the product. The movement of customers in the store is greatly influenced by the display of products in the store (Ward, Bitner \& Barnes, 1992). Many researchers describe the importance of the physical environment to shopping mall shoppers (Singh \& Prashar, 2013). According to respondents against interview $\mathrm{Q} \#$ 5;

Interview Q\# 5: What are the features of shopping Mall that force you to Page $\mid 19$ 
choose super market for monthly shopping?

Respondent 1: There are many reasons but main are reasonable and fixed prices and layout of the product.

Respondent 2: Main features which forces me to shop from super markets are sales offer, play area and food court with air condition so we can purchase things easily.

Respondent 3: The factors that force me to choose super market for monthly shopping are the design and lighting of the shopping mall.

Respondent 4: Because we can acquire a good discount on monthly shopping so, I go in shopping Mall instead of Bazar.

Respondent 5: We have many facilities in the shopping mall and we find everything under the one roof.

Respondent 6: In shopping Mall each and every thing is available at very low price and we can purchase them with enjoyment.

Respondent 7: Shopping mall provide pleasant environment with attractive design and architecture for shopping that's why it is more convenient.

Respondent 8: Shopping malls are designed preplanned for the shopping purpose with attractive features that's why shopping mall is much better for shopping purpose.

The physical environment including cleanliness, lighting, security and safety are important aspects influencing visitors in shopping centers (Ahmad, 2012). Similarly, correct use of aromas attracts customers towards shopping centers (Morrin \& Ratneshwar, 2000). Customers spend more time in shopping when the environment of the mall contains well equipped and elegant infrastructure with soft music (Yalch \& Spangenberg, 2000).

Many research studies have indicated that shopping centers have improved their own image and attractiveness due to the addition of other services such as foodcourt, relaxation, and entertainment services (Sit \& Birch, 2014). As respondents share their opinion in interview Q\# 6 as ;

Interview Q\# 6: What is your opinion about the current super store?

Respondent 1: It is very good initiative for individual who do not want to purchase only but also want to be relax with eating in pleasant environment like Dolmen Mall.

Respondent 2: I think super markets are best for shopping as well as window shopping.

Respondent 3: In the current super stores we can purchase every product at one place in decent atmosphere.

Respondent 4: We can purchase every product at one place with safety and pleasure.

Respondent 5: When anyone talks about chase or imtiaz so it is assumed that he or she may be going for grocery.

Respondent 6: It is the place where we can purchase grocery items, garments, cosmetics, shoes, fabrics, crockery in beautiful environment.

Respondent 7: They make monthly shopping easier, more comfortable and satisfactory.

Respondent 8: They are more helpful in shopping because of attractive display of 
the product.

Findings of this study suggest that store constructors (proprietors) should increase the interior landscaping features of the malls that can enhance the intention of the consumers to spend more time and money, buy more products and materialize the purchase intention. Previous studies were found that the exterior atmospheric factors have significant impact on consumer behavior which also influences customers' impulse purchasing which is unplanned and stimulated by the exterior atmosphere. The exterior design of the malls also found to be a significant factor to impact on consumer buying behavior.

\section{Managerial Implications}

This study offers a tool to measure the relationship between shopping mall interior landscape design and consumer preference and provide the help as an instrument for understanding the impact of interior landscape design. Additionally, this study has argued the key interior atmospheric factors that influence the consumer buying behavior. Therefore, for professionals and businessman, the findings of research suggest that to increase the number of footfalls in the store an effort should be emphasized on interior atmospheric factors. To end with, this study, model may help in planning the organizational communication mix for any type of a business.

\section{LIMITATIONS AND FUTURE RESEARCH}

From a bigger retail industry, some shopping malls considering interior landscape design of Karachi are selected for this study. Moreover, the respondents are selected that do frequent shopping in the malls. In this research only some factors affecting the consumer behavior are considered while other variable that may affect the foot falling are not taken in the study. These factors may be considered in future research. Even though, the study lessened the scope of the broad concepts of interior landscape design and consumer preference by targeting on specific features of malls and limiting to a particular type of retailing industry, but at the same time it increases the room for further research to fill the gaps, identified. Future researcher may consider the influence of atmospheric variable evaluating all the outlets specially designed to serve the purpose. Besides that, the future research can explore the impact of landscaping of shopping malls on various retail industries. Therefore, for professionals and businessman, the findings of research suggest that an effort should be emphasized on interior atmospheric factors to increase the number of footfalls in the store.

\section{REFERENCES:}

Akram, U., et al. (2016). "Impact of store atmosphere on impulse buying behaviour: Moderating effect of demographic variables." International Journal of u-and e-Service, Science and Technology9(7): 43-60.

Albrecht, C.-M., et al. (2017). "The relationship between consumer shopping stress and purchase abandonment in task-oriented and recreation-oriented consumers." Journal of the Academy of Marketing Science45(5): 720-740.

Page $\mid 21$ 
Ali, M. S. I., \& Mubarak, K. M. (2016). Exterior atmospherics and there impact on consumer purchasing behavior at self-serving convenience stores. International Journal of Science and Research, 5(11), 263-268.

Abratt, R., \& Goodey, S. D. (1990). Unplanned buying and in-store stimuli in supermarkets. Managerial and Decision Economics, 11(2), 111-121.

Ahmad, A. M. K. (2012). Attractiveness Factors Influencing Shoppers!'।= Satisfaction, Loyalty, and Word of Mouth: An Empirical Investigation of Saudi Arabia Shopping Malls. International Journal of Business Administration, 3(6), 101-112.

Avello, M., Gavilán, D., Abril, C., \& Manzano, R. (2011). Experiential shopping at the mall: influence on consumer behaviour. China-USA Business Review, 10 (1).

Banot, A., \& Wandebori, H. (2012). Store Design and Store Atmosphere Effect on Customer Sales per Visit. In 2nd International Conference on Business Economics, Management and Behavioral Sciences (pp. 84-89).

Bhuvaneswari, V. and J. Krishnan (2015). "A Review of Literature on Impulse Buying Behavior of Consumer in Brick to Mortar and Click Only Stores." International Journal of Management Research and Social Science2(3): 84-90.

Chithralega, J. (2013). "A study on influence of shopping motivation, mall atmosphere and value relationship with reference to mega malls in Chennai." International Journal of Marketing, Financial Services \& Management Research2(6): 145-156.

Choudhury, A., Alam, M. I., \& Islam, S. (2012). Customers' attitude towards shopping malls: a study on bashundhara city shopping mall. Du Journal Of Marketing, 15, 127-142.

Dahan-Oliel, N., et al. (2016). "Adolescents with disabilities participate in the shopping mall: facilitators and barriers framed according to the ICF." Disability and rehabilitation38(21): 2102-2113.

Das, G. and G. Varshneya (2017). "Consumer emotions: Determinants and outcomes in a shopping mall." Journal of Retailing and Consumer Services38: 177-185.

Dębek, M. (2015). "What Drives Shopping Mall Attractiveness?" Polish Journal of Applied Psychology 13(1): 67-118.

Ekeng, A., et al. (2012). "Effect of demographic characteristics on consumer impulse buying among consumers of Calabar municipality, cross river state." Academic Research International 3(2).

Goss, J. (1993). "The "magic of the mall": an analysis of form, function, and meaning in the contemporary retail built environment." Annals of the Association of American Geographers83(1): 18-47.

Hasker, K. and E. Inci (2014). "Free parking for all in shopping malls." International Economic Review55(4): 1281-1304.

Hussain, R., \& Ali, M. (2015). Effect of store atmosphere on consumer purchase intention. International Journal of Marketing Studies, 7(2).

Hami, A., Moula, F. F., \& Maulan, S. B. (2018). Public preferences toward shopping mall interior landscape design in Kuala Lumpur, Malaysia. Urban Forestry \& Urban Greening, 30, 1-7.

Huberman, A. M., \& Miles, M. B. (1994). Data management and analysis methods. Hussain, R., \& Ali, M. (2015). Effect of store atmosphere on consumer purchase intention. International Journal of Marketing Studies, 7(2). 
Kaihatu, T. S., \& Spence, M. T. (2016). The relationship between shopping mall image and congruity on customer behaviour: Evidence from Indonesia. Australasian Marketing Journal (AMJ), 24(2), 141-145.

Koul, S., \& Mishra, H. G. (2013). Customer perceptions for store attributes: A study of traditional retail stores in India. Journal of Business \& Economics, 5(1), 79.

Kumar, A., \& Singh, Y. (2014). A study of key factor affecting customer relationship towards shopping mall. International Journal of Business Quantitative Economic and Applied Management Research, 1(4), 118-127.

Kaihatu, T. S. and M. T. Spence (2016). "The relationship between shopping mall image and congruity on customer behaviour: Evidence from Indonesia." Australasian Marketing Journal (AMJ)24(2): 141-145.

Koul, S., \& Mishra, H. G. (2013). Customer perceptions for store attributes: A study of traditional retail stores in India. Journal of Business \& Economics, 5(1), 79.

Kumar, A. and Y. Singh (2014). "A study of key factor affecting customer relationship towards shopping mall." International Journal of Business Quantitative Economic and Applied Management Research1(4): 118-127.

Makgopa, S. (2016). Determining consumers' reasons for visiting shopping malls. Innovative Marketing, 12(2), 22-27.

Mittal, A. and D. Jhamb (2016). "Determinants of shopping mall attractiveness: The Indian context." Procedia Economics and Finance37: 386-390.

Makgopa, S. (2016). Determining shopping mall visitors' perceptions on mall attributes. Problems and perspectives in management, (14, Iss. 3 (contin. 2)), 522-527.

Mayring, P. (2004). Qualitative content analysis. A Companion to Qualitative Research, 1, 159-176.

Mittal, A., \& Jhamb, D. (2016). Determinants of shopping mall attractiveness: The Indian context. Procedia Economics and Finance, 37, 386-390.

Morrin, M., \& Ratneshwar, S. (2000). The impact of ambient scent on evaluation, attention, and memory for familiar and unfamiliar brands. Journal of Business Research, 49(2), 157-165.

Rabbanee, F. K., et al. (2012). "Effects of store loyalty on shopping mall loyalty." Journal of Retailing and Consumer Services19(3): 271-278.

Šeinauskienė, B., et al. (2015). "The relationship of happiness, impulse buying and brand loyalty." Procedia-Social and Behavioral Sciences213: 687-693.

Shaikh, R. A. M. A. (2017). "Latest Buyer's Need in Shopping Malls.” IBMRD's Journal of Management \& Research6(1): 52-56.

Singh, H., \& Prashar, S. (2013). Factors defining shopping experience: an analytical study of Dubai. Asian Journal of Business Research, 3(1).

Sit, J. K., \& Birch, D. (2014). Entertainment events in shopping malls_profiling passive and active participation behaviors. Journal of Consumer Behaviour, 13(6), 383-392.

Thomas, S. and B. Pathak (2012). A study of Consumer Behavior Approach towards Shopping Mall Attractiveness with special reference to the city of Ahmedabad, IRJSSM.

Varley, R. (2005). Store image as the key differentiator. European Retail Digest, (46), 18-21.

Ward, J. C., Bitner, M. J., \& Barnes, J. (1992). Measuring the prototypicality and meaning of retail environments. Journal of Retailing, 68(2), 194-221.

Page $\mid 23$ 
Yalch, R. F., \& Spangenberg, E. R. (2000). The effects of music in a retail setting on real and perceived shopping times. Journal of Business Research, 49(2), $139-147$.

\section{Questions for Interviews (For shopping)}

Interview Q\#1: Do you go for shopping by yourself or use any other mode for shopping?

Interview Q\#2: Do you think the increase in the super store has affected the status of bazaar?

Interview Q\#3: What is the difference between Super store and Bazaar?

Interview Q\#4: Which mode of shopping is beneficial for you? Traditional market (Bazar) or supermarket/store?

Interview Q\#5: What are the features of shopping Mall that force you to choose super market for monthly shopping?

Interview Q\#6: What is your opinion about the current super store?

Interview Q\#7: What comes in your mind while selecting super store?

Interview Q\#8: Name the super store you visit frequently?

Interview Q\#9: Rank any three super stores which come first in your mind before shopping?

Interview Q\#10: What are the reasons to choose these stores?

Interview Q\#11: What are the disadvantages of these stores?

Interview Q\#12: What are the problems you face when you enter in the super markets?

Interview Q\#13: What is the difference you see in super store format and services after increasing competition?

Interview Q\#14: Do you understand that Children play area in shopping malls is needed?

Interview Q\# 15: What is your opinion about Atmosphere of shopping mall?

Interview Q\#16: Are you satisfied with the products available in the super stores?

Interview Q\#17: What is your opinion about sales and promotion of products?

Does these

Promotions attract you for shopping?

Interview Q\#18: Do you understand that Security and Safety in shopping malls is necessary? 